\title{
Household income is associated with food and nutrient intake in Japanese schoolchildren, especially on days without school lunch
}

\author{
Nobuko Murayama ${ }^{1, *}$, Hiromi Ishida ${ }^{2}$, Taeko Yamamoto ${ }^{3}$, Sayaka Hazano ${ }^{4}$, \\ Akemi Nakanishi ${ }^{2}$, Yumi Arai ${ }^{2}$, Miho Nozue ${ }^{2,5}$, Yukiko Yoshioka ${ }^{6}$, Saori Saito ${ }^{6}$ and Aya Abe ${ }^{7}$ \\ 'Department of Health and Nutrition, University of Niigata Prefecture, 417 Ebigase, Higashiku, Niigata 950-8680, \\ Japan: ${ }^{2}$ Department of Applied Nutrition, Kagawa Nutrition University, Sakado, Saitama, Japan: ${ }^{3}$ Department \\ of Nutrition, Kanagawa University of Human Services, Yokosuka, Kanagawa, Japan: ${ }^{4}$ Department of Health and \\ Nutrition, Matsumoto University, Matsumoto, Nagano, Japan: ${ }^{5}$ Epidemiology and Prevention Division, National \\ Cancer Center Research Institute, Tokyo, Japan: 'Department of Nutritional Management, Sagami Women's \\ University, Sagamihara, Kanagawa, Japan: ${ }^{7}$ Graduate School of Humanities, Tokyo Metropolitan University, \\ Tokyo, Japan
}

Submitted 18 September 2016: Final revision received 3 April 2017: Accepted 3 May 2017: First published online 30 August 2017

\begin{abstract}
Objective: The present study aimed to examine the association between household income and the intake of foods and nutrients by Japanese schoolchildren, and any differences between days with and without school lunch. Design: This was a cross-sectional study. Children, with the support of their parents, kept dietary records with photographs for $4 \mathrm{~d}$ ( $2 \mathrm{~d}$ with school lunch and $2 \mathrm{~d}$ without). The socio-economic status of each family was obtained from a questionnaire completed by the parents.

Setting: Japan.

Subjects: All students in 5th grade (10-11 years old) at nineteen schools in four prefectures and their parents (1447 pairs of students and parents) were invited to take part in the study; 836 pairs of complete data sets were analysed.

Results: The average results of four days of dietary records showed that lower income level was associated with a lower intake of fish/shellfish, green vegetables and sugar at the food group level, a lower intake of protein and several micronutrients, and a higher energy intake from carbohydrates at the nutrient level among the children. These associations between income and food/nutrient intake were not significant on days with school lunches, but were significant on days without school lunch.

Conclusions: Our study confirmed an association between household income and the amount of foods and nutrients consumed by Japanese schoolchildren, and suggested that school lunches play a role in reducing disparities in the diets of children from households with various incomes.
\end{abstract}

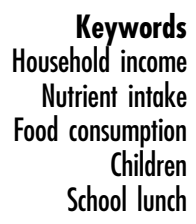

Socio-economic inequalities in health have been widely studied in industrialized countries. Many health indicators of morbidity and mortality are positively associated with low socio-economic status (SES) ${ }^{(1)}$. Furthermore, lower socio-economic groups have a higher incidence of non-communicable diseases than those in more socioeconomically advantaged groups ${ }^{(2,3)}$. Dietary factors may contribute to the impact of morbidity and mortality related to chronic diseases. Adults of high SES tend to consume a healthy diet, with greater consumption of fruit, vegetables and whole-grain foods, whereas those of low SES are more likely to consume fatty meats and refined cereals ${ }^{(4-9)}$.

Many studies have shown that children and adolescents from low-SES backgrounds in Western countries are more likely to be obese ${ }^{(10,11)}$ and low SES in childhood is associated with obesity in adult women ${ }^{(12)}$. It is suggested that children from low-SES households in Western countries have less healthy diets, such as lower consumption of vegetables, fruits, fish, fibre-rich bread and low-fat milk, and higher consumption of meat products, soft drinks and energy-dense foods ${ }^{(13-17)}$. In addition to cross-sectional studies, a prospective study found causal associations between lower SES and unhealthy dietary profiles among European children $^{(18)}$. These studies used FFQ to evaluate dietary quality between different SES. Previous studies using dietary recall/records suggest that children in households with lower incomes consume less Ca, vitamin D and dairy foods in Canada ${ }^{(19)}$, and a Korean study showed that they 
obtain less energy from protein and higher energy from carbohydrates $^{(20)}$. A systematic review revealed a positive association between SES and micronutrient intake in children; however, only a few studies have been published $^{(21)}$.

Very few studies on SES and health/diet have been reported in Japan, because Japanese society is considered an egalitarian society ${ }^{(22)}$. However, income inequality in Japan has risen since the $1980 \mathrm{~s}^{(23)}$ and studies on SES and health, mostly in adults, have been conducted since the $1990 s^{(24)}$. Some studies show an association between household SES and diet in adults ${ }^{(25,26)}$. The child poverty rate has increased in Japan ${ }^{(23)}$; thus, an act to accelerate measures for disadvantaged children was enacted in 2013. However, there is little evidence of an association between household income and the diets of children in Japan. Only one study of pre-school children has been published $^{(27)}$ and the results suggested that household income is not associated with child diet after adjustment for maternal education. However, the study was limited to a homogeneous population of pregnant women in one city and the frequency of the children's food consumption was reported by the mothers. Further studies are needed to examine the associations between household income and the dietary intake of children.

School lunches have been part of an important policy to improve child nutrition in Japan since World War II ${ }^{(28,29)}$ and school lunch coverage was $98.4 \%$ at primary schools in fiscal year $2014^{(30)}$. Previous studies in the USA suggested that participation in the national school lunch programme could modify the relationship between food insecurity and weight in school-aged children ${ }^{(31-34)}$. Thus, we hypothesized that the school lunch programme would reduce potential disparities in diet due to household income among schoolchildren in Japan. Moreover, we thought that there may be some differences in the association between household income and diet in children on the days with school lunches compared with the days without. If the effects of household income on diet were less on days with school lunches than on days without, this would suggest that school lunches have a beneficial role. This hypothesis has not been examined in previous studies.

Therefore, the objectives of the present study were to examine the association between household income and food and nutrient intake among Japanese primary-school children and to determine potential differences between days with and without school lunches.

\section{Methods}

\section{Study participants}

The participants of the present study were all 5 th grade children (10-11 years old) attending nineteen primary schools in four areas (prefectures) of East Japan. There were 1498 children registered and, after excluding children who had been absent for long periods, 1447 pairs of children and guardians were included.

Among the four areas, areas A (three schools in two cities) and $\mathrm{C}$ (eight schools in one city and one village) were rural residential areas, and areas $\mathrm{B}$ (six schools in one city) and D (two schools in one city) were urban residential areas. The schools were selected from public schools after we obtained permission from the respective Boards of Education of the cities and head teachers of the primary schools. Children in 5th grade were selected because they were able to complete a questionnaire, keep dietary records and take photographs of the foods they ate. In addition, 5 th grade children are less busy at school than 6th grade children. Among the 1447 pairs, 1231 ( $85.1 \%)$ child-guardian pairs agreed to participate in the study. We excluded 307 pairs who did not provide information about income, eighty-two pairs who did not complete four days of dietary records, five pairs who did not provide information about body height and weight, and one pair who did not answer the frequency of exercise questions; thus 836 pairs $(57 \cdot 8 \%)$ were included in the present study.

\section{Measures}

Data were collected from September to December 2013.

\section{Housebold socio-economic status and demographic characteristics}

The parents/guardians of the children completed questionnaires on household SES and demographic characteristics. The questionnaires were distributed to the children at school and taken home for the parents to complete. Children returned the questionnaires to schools where they were collected for the study. The SES of participants was assessed as household income and level of education of the fathers and mothers of the children.

Participants were asked about their total annual household income, including salary, social benefits, family allowance and rental income of all household members during fiscal year 2012. Participants selected one of the following choices: (i) 'less than 1 million yen'; (ii) ' 1 to less than 2 million yen'; (iii) ' 2 to less than 3 million yen'; (iv) ' 3 to less than 4 million yen'; (v) ' 4 to less than 6 million yen'; (vi) ' 6 to less than 8 million yen'; (vii) ' 8 million yen and over'; or (viii) 'do not wish to answer'. The choice to limit responses to these options rather than use open questions was made to increase the response rate. We used narrower ranges for incomes of less than 4 million yen to reveal the income level that affected diet among low-income households. We included the choice 'do not wish to answer' for ethical reasons to protect the participants' human rights. For each response, we calculated the equivalent household income by dividing the income by the square root of the number of household members ${ }^{(35)}$. To calculate equivalent household incomes, the midpoints of each income 
category $^{(36)}$ - i.e. $0.5,1 \cdot 5,2.5,3.5,5,7$ and 9 million yen - were used to represent incomes, respectively. We divided the income variables into three categories as follows: low ( 0.2236 to 2.2361 million yen; $n 319$ ), middle ( 2.3333 to 2.8868 million yen; $n$ 194) and high ( 3.1305 to 6.3640 million yen; $n$ 323) income groups. The numbers of participants in each of the three income groups were not equal because many participants had the same income. The median incomes for these groups were 1.75 million yen, 2.50 million yen and 3.50 million yen, respectively.

To assess educational attainment of parents, participants were asked about their highest level of education: (i) 'middle school'; (ii) 'high school'; (iii) 'vocational/junior college'; (iv) 'university/graduate school'; and (v) 'do not wish to answer'. Demographic variables included the number of household members who shared the household income.

\section{Confounding factors of children}

Factors related to the diets of the children were determined by questionnaire and recorded information. The children completed questionnaires in the classrooms at the schools together. The variables included sex, frequency of exercise and foods allergy/food restriction. Children were asked how frequently they exercised (including outdoor play and excluding exercise class at school) per week. The children selected one of the following choices: (i) ' 5 days/ week or more'; (ii) '3-4 days/week'; (iii) '1-2 days/week'; or (vi) '0 days/week'. Children were asked about the presence or absence of food allergies/food restrictions as part of clinical treatment, and the details. Children's height and body weight were measured at school according to the manual for school check-up ${ }^{(37)}$ in September 2013. BMI was calculated as body weight divided by the square of height $\left(\mathrm{kg} / \mathrm{m}^{2}\right)$. Degree of obesity was calculated according to school health statistics in $\operatorname{Japan}^{(37)}$ : degree of obesity $(\%)=$ [body weight $(\mathrm{kg})$ - standard body weight for height $(\mathrm{kg})] /[$ standard body weight for height $(\mathrm{kg})] \times 100$.

\section{Dietary records of children}

Children completed four consecutive days of $24 \mathrm{~h}$ dietary records with photographs. Two days with school lunches (weekdays) and two days without (weekend days) were recorded. Children recorded the names and amounts of all foods and beverages consumed at breakfast, lunch, dinner and other occasions. A camera, place mat with a graded scale (with which we could confirm the size of the tableware and amount of food), dietary record sheets for four days and instructions on keeping records were distributed to each child. The trained researcher explained how to record information and how to take photographs of meals to all participating children in each classroom using the same manual for dietary records. Thereafter, the children were trained to record information and take photographs during school lunch on the training day. Children were asked to put all dishes/foods on the place mat before eating, take photographs, and record the time of the meal, dish name, names of the foods, amounts of the foods, amounts of additional helpings and amounts of leftovers. Children were asked to take photographs after eating to confirm the amount of food left over. They were also asked to weigh the foods when possible and write the commercial name of the food if the food was processed. Parents/guardians were asked to support and confirm the records kept by the children. The children took school lunches on two school days. We printed the school lunch menu for each day on the record sheets.

\section{Analysis of the dietary records}

We used Excel Eiyo-Kun version 7.0, 2nd edition software (Kenpakusya, Tokyo, Japan), which is based on published standard tables of food composition in Japan 2010, to calculate energy values and nutrients. Fortified foods were considered in the present study and the nutrients recorded were thiamin, riboflavin, vitamin $\mathrm{C}, \mathrm{Ca}$ and Fe. We added the amounts of nutrients when children consumed fortified foods and we were able to find the nutrient values. We compiled a manual for the analysis of dietary records, and registered dietitians identified the food name and amount of food from the records and photographs. The registered dietitians were recruited only for analysing the dietary records and were not informed about the socioeconomic and demographic data of the participants. When the amounts of foods and nutrients were calculated, cooked values of foods and weights were used for cereals, rice, noodles, breads and beans (taking into account loss of nutrients during cooking), while raw values of foods and weights were used for vegetables, meat, fish and others (did not take into account loss of nutrients during cooking).

For school lunches, we obtained data on the average amounts of foods and nutrients per person on each recorded day. Photographs of standard amounts of school lunch items were taken by the school dietitian/researcher each day at each school. These photographs were compared with the photographs taken by each child when s/he had school lunches to identify the amounts of the foods eaten by each child.

Participants who completed dietary records for four days were included in the present study. School lunch is served for about $190 \mathrm{~d} /$ year in public primary schools in $\operatorname{Japan}^{(30)}$, which is roughly half of all days in a given calendar year. Thus, the levels of intake of nutrients/foods from the averages of the four days were used to assess average intake levels for one year.

\section{Statistical analysis}

Numerical variables were expressed as means and SD or $95 \% \mathrm{CI}$, and as percentages of participants for categorical variables. The $\chi^{2}$ test was used to compare the characteristics of the participants as categorical data among 
household incomes, and one-way ANOVA was used for body weight, height and degree of obesity of the children. Differences in means for nutrient and food intakes among household incomes were analysed using linear mixedeffects models, taking into account a random effect (prefecture and school), fixed effects (sex, exercise, allergy of child, father's and mother's educational attainments) and a covariate (BMI of child). Amounts of differences in nutrient and food intakes between low-income and middle/high-income groups adjusted for confounding factors explained above were also calculated. Tests for trend association were performed by modelling the median value of each category of household income as a continuous variable. Two-tailed $P$ value of $<0.05$ was considered statistically significant. All analyses were performed using the statistical software package IBM SPSS Statistics version 21.0.

\section{Results}

\section{Study population}

The characteristics of the participants and income levels are shown in Table 1 . The study population consisted of 409 boys and 427 girls. Significant differences in demographic and socio-economic variables existed among the three income groups, such as prefecture, educational attainment of fathers and mothers, household annual income and number of family members (all $P<0 \cdot 001$ ), but there were no differences in sex, frequency of exercise (excluding physical education class), presence or absence of food allergy, height, body weight, BMI and degree of obesity among the children.

\section{Associations between bousebold income and diet: average over $4 d$}

Results of the analysis of associations between household income and diet given as averages over $4 \mathrm{~d}$ are shown in Table 2. The results showed that the low-income group consumed less protein, animal protein, energy from protein, $\alpha$-tocopherol, niacin, vitamin $\mathrm{B}_{12}$, pantothenic acid, $\mathrm{Mg}, \mathrm{P}, \mathrm{Fe}, \mathrm{Zn}$ and $\mathrm{Cu}$ at the nutrient level, and sugar, green vegetables and fish/shellfish at the food group level, than those of the higher income groups after adjusting for confounding factors (all $P<0.05$ for $P$ value or $P$ for trend). Energy obtained from carbohydrates was higher in the low-income group than in the higher income groups $(P<0.05$ for $P$ value and $P$ for trend). There was no difference in total energy intake levels among the income groups.

\section{Associations between bousebold income and diet on the days with/witbout school lunch}

The results of analysis of the associations between household income and diet among averages over $2 \mathrm{~d}$ with school lunches are shown in Table 3 . The results show that there were no significant differences in the amounts of nutrients or foods consumed among the income groups.

The results from analysis of the associations between household income and diet from averages over $2 \mathrm{~d}$ without school lunches are shown in Table 4 . The results showed strong associations between household income and nutrient and food consumption. The low-income group consumed less protein, animal protein, cholesterol, energy from protein, $\alpha$-tocopherol, niacin, vitamin $\mathrm{B}_{12}$, pantothenic acid, $\mathrm{K}, \mathrm{Mg}, \mathrm{P}, \mathrm{Fe}, \mathrm{Zn}$ and $\mathrm{Cu}$ at the nutrient level, and sugar, green vegetables, fish/shellfish and meats/poultry at the food group level, than those in the higher income groups (all $P<0.05$ for $P$ value or $P$ for trend). The energy obtained from carbohydrates was higher in the low-income group than in the higher-income groups $(P<0.05$ for $P$ value and $P$ for trend).

\section{Discussion}

The findings of the present study using $4 \mathrm{~d}$ dietary records confirm the association between household income and amounts of foods and nutrients consumed among Japanese schoolchildren. The results suggested that the lower levels of protein and micronutrients, and higher percentage of energy from carbohydrate consumed by children from low-income households compared with higherincome groups were caused by a lower consumption of protein foods and green vegetables. This means that fewer main dishes (fish, etc.) and side dishes (vegetables, etc.) were consumed, while staple foods (rice, noodles, bread and cereals) constitute the meals of children from lowincome households. An additional contribution of the study is that our data showed modification of the association between household income and the foods and nutrients consumed by children on days both with and without school lunches. No significant disparities in the foods and nutrients consumed among household income groups occurred in the days with school lunch compared with those without. This finding provides evidence to show that the school lunch programme may reduce diet disparities due to different household economic status among children.

\section{Nutritional status}

Previous studies showed an inverse relationship between household income and the prevalence of obesity in Western developed countries ${ }^{(10-12)}$. However, there were no significant associations between income, height, body weight and degree of obesity in the present study. Kwon et al. reported a positive relationship between household income and the prevalence of obesity in Korean boys (7-12 years old ${ }^{(20)}$. Furthermore, Kachi et al. reported that lower household incomes and expenditures were associated with a risk of being 
Table 1 Characteristics of participants by income level: 5th grade children (10-11 years old) at nineteen schools in four prefectures and their parents, Japan, September-December 2013

\begin{tabular}{|c|c|c|c|c|c|c|c|c|c|c|}
\hline \multirow[b]{2}{*}{ Variable } & \multirow[b]{2}{*}{ Category } & \multicolumn{2}{|c|}{$\begin{array}{c}\text { Total } \\
(n \text { 836) }\end{array}$} & \multicolumn{2}{|c|}{$\begin{array}{l}\text { Low income } \\
\quad(n \text { 319) }\end{array}$} & \multicolumn{2}{|c|}{$\begin{array}{l}\text { Middle income } \\
\quad(n \text { 194) }\end{array}$} & \multicolumn{2}{|c|}{$\begin{array}{l}\text { High income } \\
\quad(n \text { 323) }\end{array}$} & \multirow[b]{2}{*}{$P$ value ${ }^{*}$} \\
\hline & & $n$ & $\%$ & $n$ & $\%$ & $n$ & $\%$ & $n$ & $\%$ & \\
\hline \multirow[t]{4}{*}{ Prefecture of residency } & A & 188 & $22 \cdot 5$ & 71 & $22 \cdot 3$ & 44 & $22 \cdot 7$ & 73 & $22 \cdot 6$ & $<0.001$ \\
\hline & B & 221 & $26 \cdot 4$ & 62 & $19 \cdot 4$ & 73 & $37 \cdot 6$ & 86 & $26 \cdot 6$ & \\
\hline & C & 283 & 33.9 & 151 & $47 \cdot 3$ & 44 & $22 \cdot 7$ & 88 & $27 \cdot 3$ & \\
\hline & D & 144 & $17 \cdot 2$ & 35 & $11 \cdot 0$ & 33 & $17 \cdot 0$ & 76 & 23.5 & \\
\hline \multirow[t]{2}{*}{ Sex of child } & Male & 409 & $48 \cdot 9$ & 151 & $47 \cdot 3$ & 99 & $51 \cdot 0$ & 159 & $49 \cdot 2$ & 0.71 \\
\hline & Female & 427 & $51 \cdot 1$ & 168 & $52 \cdot 7$ & 95 & $49 \cdot 0$ & 164 & $50 \cdot 8$ & \\
\hline \multirow{4}{*}{$\begin{array}{l}\text { Exercise of child } \\
\text { (except physical education class) }\end{array}$} & $>5 \mathrm{~d} /$ week & 296 & 35.4 & 108 & 33.9 & 77 & 39.7 & 111 & 34.4 & $0 \cdot 17$ \\
\hline & 3-4 d/week & 296 & 35.4 & 127 & $39 \cdot 8$ & 53 & $27 \cdot 3$ & 116 & $35 \cdot 9$ & \\
\hline & $1-2 \mathrm{~d} /$ week & 199 & 23.8 & 67 & $21 \cdot 0$ & 54 & $27 \cdot 8$ & 78 & $24 \cdot 1$ & \\
\hline & $0 \mathrm{~d} /$ week & 45 & $5 \cdot 4$ & 17 & $5 \cdot 3$ & 10 & $5 \cdot 2$ & 18 & $5 \cdot 6$ & \\
\hline \multirow[t]{2}{*}{ Food allergy of child } & Yes & 71 & 8.5 & 27 & 8.5 & 14 & $7 \cdot 2$ & 30 & $9 \cdot 3$ & 0.72 \\
\hline & No & 765 & 91.5 & 292 & 91.5 & 180 & $92 \cdot 8$ & 293 & $90 \cdot 7$ & \\
\hline \multirow[t]{5}{*}{ Educational level of father } & Don’t know & 36 & $4 \cdot 3$ & 32 & $10 \cdot 0$ & 3 & 1.5 & 1 & 0.3 & $<0.001$ \\
\hline & Less than high school & 48 & $5 \cdot 7$ & 28 & $8 \cdot 8$ & 9 & 4.6 & 11 & 3.4 & \\
\hline & High school & 298 & $35 \cdot 7$ & 131 & $41 \cdot 1$ & 70 & $36 \cdot 2$ & 97 & $30 \cdot 0$ & \\
\hline & Vocational/junior college & 161 & $19 \cdot 3$ & 67 & $21 \cdot 0$ & 48 & $24 \cdot 7$ & 46 & $14 \cdot 2$ & \\
\hline & University/graduate school & 293 & $35 \cdot 0$ & 61 & $19 \cdot 1$ & 64 & 33.0 & 168 & $52 \cdot 1$ & \\
\hline \multirow{5}{*}{ Educational level of mother } & Don't know & 5 & 0.6 & 4 & $1 \cdot 3$ & 0 & 0.0 & 1 & 0.3 & 0.001 \\
\hline & Less than high school & 17 & $2 \cdot 0$ & 11 & 3.4 & 5 & $2 \cdot 6$ & 1 & 0.3 & \\
\hline & High school & 308 & $36 \cdot 8$ & 132 & 41.4 & 82 & $42 \cdot 3$ & 94 & $29 \cdot 1$ & \\
\hline & Vocational/junior college & 385 & $46 \cdot 1$ & 149 & $46 \cdot 7$ & 88 & $45 \cdot 3$ & 148 & $45 \cdot 8$ & \\
\hline & University/graduate school & 121 & 14.5 & 23 & $7 \cdot 2$ & 19 & $9 \cdot 8$ & 79 & 24.5 & \\
\hline \multirow[t]{7}{*}{ Household annual income (million yen) } & $<1$ & 6 & 0.7 & 6 & 1.9 & 0 & 0.0 & 0 & 0.0 & $<0.001$ \\
\hline & 1 to $<2$ & 36 & $4 \cdot 3$ & 36 & $11 \cdot 3$ & 0 & 0.0 & 0 & 0.0 & \\
\hline & 2 to $<3$ & 61 & $7 \cdot 3$ & 61 & $19 \cdot 2$ & 0 & 0.0 & 0 & 0.0 & \\
\hline & 3 to $<4$ & 103 & $12 \cdot 3$ & 101 & $31 \cdot 7$ & 2 & 1.0 & 0 & 0.0 & \\
\hline & 4 to $<6$ & 275 & 33.0 & 115 & $36 \cdot 1$ & 157 & $81 \cdot 0$ & 3 & 0.9 & \\
\hline & 6 to $<8$ & 215 & $25 \cdot 7$ & 0 & 0.0 & 35 & $18 \cdot 0$ & 180 & $55 \cdot 8$ & \\
\hline & 8 and over & 140 & $16 \cdot 7$ & 0 & 0.0 & 0 & 0.0 & 140 & 43.3 & \\
\hline \multirow[t]{9}{*}{ Number of family members } & 2 & 20 & $2 \cdot 4$ & 11 & 3.4 & 2 & 1.0 & 7 & $2 \cdot 2$ & $<0.001$ \\
\hline & 3 & 93 & $11 \cdot 1$ & 39 & $12 \cdot 2$ & 29 & 14.9 & 25 & $7 \cdot 7$ & \\
\hline & 4 & 373 & $44 \cdot 7$ & 81 & $25 \cdot 4$ & 128 & $66 \cdot 1$ & 164 & $50 \cdot 8$ & \\
\hline & 5 & 230 & $27 \cdot 5$ & 132 & $41 \cdot 4$ & 0 & 0.0 & 98 & $30 \cdot 3$ & \\
\hline & 6 & 81 & $9 \cdot 7$ & 33 & $10 \cdot 3$ & 28 & 14.4 & 20 & $6 \cdot 2$ & \\
\hline & 7 & 32 & $3 \cdot 8$ & 19 & $6 \cdot 0$ & 6 & $3 \cdot 1$ & 7 & $2 \cdot 2$ & \\
\hline & 8 & 6 & 0.7 & 4 & $1 \cdot 3$ & 0 & 0.0 & 2 & 0.6 & \\
\hline & 9 & 1 & 0.1 & 0 & 0.0 & 1 & 0.5 & 0 & 0.0 & \\
\hline & & Mean & $\mathrm{SD}$ & Mean & SD & Mean & SD & Mean & SD & $P$ value \\
\hline \multirow[t]{4}{*}{ Physique of child } & Body height $(\mathrm{cm})$ & $142 \cdot 7$ & $7 \cdot 0$ & $142 \cdot 7$ & 7.4 & $142 \cdot 2$ & $7 \cdot 3$ & $143 \cdot 1$ & $6 \cdot 4$ & 0.40 \\
\hline & Body weight (kg) & $35 \cdot 8$ & 7.5 & 35.4 & $7 \cdot 2$ & $36 \cdot 1$ & $8 \cdot 2$ & $36 \cdot 0$ & 7.5 & 0.52 \\
\hline & BMI $\left(\mathrm{kg} / \mathrm{m}^{2}\right)$ & $17 \cdot 4$ & $2 \cdot 7$ & $17 \cdot 3$ & 2.5 & $17 \cdot 7$ & $2 \cdot 8$ & $17 \cdot 5$ & $2 \cdot 7$ & 0.24 \\
\hline & Degree of obesity (\%)‡ & -1.9 & $14 \cdot 0$ & $-2 \cdot 6$ & 13.4 & -0.3 & $14 \cdot 4$ & $-2 \cdot 2$ & $14 \cdot 4$ & 0.16 \\
\hline
\end{tabular}

${ }^{*} P$ value for $X^{2}$ test among income levels.

$\dagger P$ value for one-way ANOVA test among income levels.

‡Degree of obesity $(\%)=[$ body weight $(\mathrm{kg})$ - standard body weight for height $(\mathrm{kg})] /[$ standard body weight for height $(\mathrm{kg})] \times 100$.

overweight in Japanese adolescents (12-18 years old), but no significant associations were found for younger children (6-11 years old $)^{(38)}$. The association between household income and the prevalence of obesity among primary-school children in Asian developed countries is not clear.

\section{Associations between bousebold income and diet of children}

Strong associations were found between household income and nutrient intake of the children in the present study. The low-income group obtained less energy from protein and higher energy from carbohydrates than the high-income group for Japanese children. The same results were observed among Korean boys; however, as household income increased, the intake of energy from carbohydrates increased and that from protein decreased in American boys ${ }^{(20)}$. Our study also showed a strong positive association between income and micronutrient intake. The same positive association is observed between SES and micronutrient intake among children in Western countries $^{(19,21)}$.

Our study suggested that the lower levels of nutrients, protein and micronutrients consumed by children from 


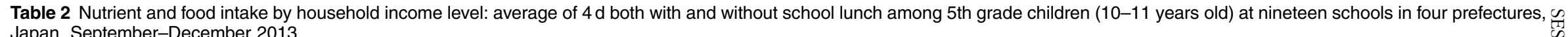
Japan, September-December 2013

\begin{tabular}{|c|c|c|c|c|c|c|c|c|c|c|c|c|}
\hline \multirow[b]{3}{*}{ Energy/nutrient/food group } & \multicolumn{2}{|c|}{ Low income ( $n$ 319) } & \multicolumn{4}{|c|}{ Middle income ( $n$ 194) } & \multicolumn{4}{|c|}{ High income ( $n$ 323) } & \multirow[b]{3}{*}{$P$ value $\ddagger$} & \multirow{3}{*}{$P$ for trend $\S$} \\
\hline & \multirow[b]{2}{*}{ Mean* } & \multirow[b]{2}{*}{$S D^{*}$} & \multirow[b]{2}{*}{ Mean* } & \multirow[b]{2}{*}{$\mathrm{SD}^{*}$} & \multicolumn{2}{|c|}{ Difference from low income } & \multirow[b]{2}{*}{ Mean* } & \multirow[b]{2}{*}{$\mathrm{SD}^{*}$} & \multicolumn{2}{|c|}{ Difference from low income } & & \\
\hline & & & & & Mean† & $95 \% \mathrm{Cl} \dagger$ & & & Mean† & $95 \% \mathrm{Cl} \dagger$ & & \\
\hline \multicolumn{13}{|l|}{ Energy and nutrients } \\
\hline Energy (kJ) & 7962 & 1331 & 8096 & 1251 & 42 & $-192,280$ & 8263 & 1351 & 176 & $-42,389$ & 0.25 & 0.10 \\
\hline Energy (kcal) & 1903 & 318 & 1935 & 299 & 10 & $-46,67$ & 1975 & 323 & 42 & $-10,93$ & 0.25 & 0.10 \\
\hline Protein (g) & 69.6 & $12 \cdot 1$ & 71.6 & 12.5 & 1.5 & $-0.7,3.7$ & 73.5 & $12 \cdot 8$ & $3 \cdot 3$ & $1 \cdot 2,5 \cdot 3$ & 0.008 & 0.002 \\
\hline Animal protein $(\mathrm{g})$ & $39 \cdot 3$ & 9.0 & $41 \cdot 6$ & 9.9 & 1.7 & $-0.1,3.5$ & $42 \cdot 4$ & $10 \cdot 2$ & $2 \cdot 9$ & $1 \cdot 3,4.5$ & 0.002 & $<0.001$ \\
\hline Lipids (g) & 62.4 & $13 \cdot 9$ & $65 \cdot 1$ & $13 \cdot 9$ & 1.4 & $-1 \cdot 2,4 \cdot 0$ & $65 \cdot 7$ & 14.7 & $2 \cdot 2$ & $-0 \cdot 1,4 \cdot 6$ & 0.18 & 0.07 \\
\hline Saturated fat (g) & 20.01 & $5 \cdot 12$ & 20.90 & $5 \cdot 35$ & 0.53 & $-0.44,1.50$ & $20 \cdot 82$ & 5.40 & 0.40 & $-0.50,1.25$ & 0.53 & 0.46 \\
\hline Cholesterol (mg) & $345 \cdot 3$ & $107 \cdot 4$ & 362.9 & $113 \cdot 2$ & $15 \cdot 7$ & $-4 \cdot 6,36 \cdot 1$ & $360 \cdot 7$ & $110 \cdot 0$ & $16 \cdot 2$ & $-2 \cdot 3,34.8$ & 0.17 & 0.10 \\
\hline Carbohydrate (g) & 258.6 & 44.8 & 258.4 & 39.1 & $-2 \cdot 0$ & $-9 \cdot 9,5 \cdot 8$ & 265.5 & $46 \cdot 2$ & $2 \cdot 3$ & $-4.8,9.5$ & 0.53 & 0.47 \\
\hline Dietary fibre (g) & 12.4 & 3.0 & 12.4 & 2.6 & 0.1 & $-0.4,0.7$ & 12.8 & 2.9 & 0.2 & $-0.3,0.7$ & 0.71 & 0.43 \\
\hline Energy from protein (\%) & 14.7 & 1.4 & $14 \cdot 8$ & 1.3 & 0.1 & $-0.1,0.4$ & $15 \cdot 0$ & 1.5 & 0.3 & $0.1,0.6$ & 0.021 & 0.005 \\
\hline Energy from fat (\%) & $29 \cdot 1$ & 3.4 & 29.9 & 3.4 & 0.5 & $-0 \cdot 1,1 \cdot 2$ & $29 \cdot 6$ & 3.7 & 0.5 & $-0 \cdot 1,1 \cdot 1$ & 0.18 & 0.12 \\
\hline Energy from carbohydrate (\%) & $56 \cdot 2$ & $3 \cdot 8$ & $55 \cdot 3$ & 3.8 & -0.7 & $-1 \cdot 4,0 \cdot 1$ & 55.4 & $4 \cdot 2$ & -0.8 & $-1 \cdot 5,-0.2$ & 0.039 & 0.018 \\
\hline Retinol activity equivalents $(\mu \mathrm{g})$ & 490 & 160 & 516 & 202 & 20 & $-17,57$ & 526 & 236 & 7 & $-27,41$ & 0.56 & 0.76 \\
\hline Vitamin D $(\mu \mathrm{g})$ & 5.7 & $3 \cdot 2$ & 5.9 & 3.4 & 0.2 & $-0.5,0.8$ & 6.4 & 4.1 & 0.5 & $-0 \cdot 1,1 \cdot 1$ & 0.19 & 0.07 \\
\hline a-Tocopherol (mg) & 6.5 & $1 \cdot 7$ & 6.6 & 1.6 & 0.2 & $-0.1,0.5$ & $6 \cdot 8$ & $1 \cdot 7$ & 0.3 & $0.0,0.6$ & $0 \cdot 10$ & 0.033 \\
\hline Vitamin $\mathrm{K}(\mu \mathrm{g})$ & 182 & 78 & 188 & 77 & 7 & $-7,21$ & 190 & 75 & 3 & $-10,16$ & 0.61 & 0.75 \\
\hline Thiamin (mg) & $1 \cdot 13$ & 0.24 & $1 \cdot 16$ & 0.25 & 0.10 & $0.00,0.10$ & 1.15 & 0.25 & 0.00 & $-0.04,0.04$ & 0.98 & 0.94 \\
\hline Riboflavin (mg) & 1.23 & 0.33 & 1.27 & 0.31 & 0.00 & $0.00,0.10$ & 1.28 & 0.28 & 0.03 & $-0.02,0.08$ & 0.34 & 0.35 \\
\hline Niacin equivalents (mg) & $27 \cdot 7$ & 5.5 & 28.9 & $5 \cdot 3$ & 0.8 & $-0.2,1.8$ & 29.5 & 5.9 & 1.4 & $0.5,2.4$ & 0.010 & 0.003 \\
\hline Vitamin $B_{6}(\mathrm{mg})$ & $1 \cdot 19$ & 0.49 & 1.24 & 0.32 & 0.00 & $0.00,0.10$ & 1.24 & 0.28 & 0.03 & $-0.04,0.09$ & 0.60 & 0.44 \\
\hline Vitamin $B_{12}(\mu \mathrm{g})$ & $5 \cdot 2$ & 2.5 & $5 \cdot 6$ & $2 \cdot 7$ & 0.4 & $-0.1,1.0$ & $6 \cdot 1$ & $3 \cdot 6$ & 0.9 & $0.4,1.4$ & 0.002 & 0.001 \\
\hline Folate $(\mu \mathrm{g})$ & 269 & 71 & 268 & 67 & 4.0 & $-8,16$ & 281 & 72 & 6 & $-5,18$ & 0.53 & 0.27 \\
\hline Pantothenic acid (mg) & $6 \cdot 29$ & 1.25 & 6.53 & $1 \cdot 21$ & 0.20 & $0.00,0.40$ & 6.62 & $1 \cdot 23$ & 0.22 & $0.02,0.42$ & 0.07 & 0.041 \\
\hline Biotin $(\mu \mathrm{g})$ & $29 \cdot 6$ & $8 \cdot 1$ & $30 \cdot 2$ & $7 \cdot 8$ & 0.9 & $-0.5,2.4$ & $30 \cdot 8$ & $8 \cdot 7$ & 0.8 & $-0 \cdot 6,2 \cdot 1$ & 0.38 & 0.29 \\
\hline Vitamin C (mg) & 98 & 43 & 105 & 89 & 5 & $-5,16$ & 102 & 39 & -3 & $-12,6$ & 0.26 & 0.43 \\
\hline $\mathrm{Na}(\mathrm{mg})$ & 3650 & 674 & 3711 & 703 & 12 & $-114,138$ & 3786 & 713 & 67 & $-48,182$ & 0.48 & 0.24 \\
\hline $\mathrm{K}(\mathrm{mg})$ & 2311 & 505 & 2382 & 446 & 66 & $-22,154$ & 2439 & 485 & 69 & $-11,149$ & 0.18 & $0 \cdot 11$ \\
\hline $\mathrm{Ca}(\mathrm{mg})$ & 561 & 158 & 573 & 164 & 11 & $-19,41$ & 588 & 162 & 11 & $-16,38$ & 0.67 & 0.44 \\
\hline $\mathrm{Mg}(\mathrm{mg})$ & 220 & 46 & 224 & 41 & 4 & $-5,12$ & 233 & 45 & 9 & 1,16 & 0.07 & 0.021 \\
\hline$P(\mathrm{mg})$ & 1057 & 200 & 1088 & 201 & 24 & $-13,60$ & 1114 & 202 & 40 & 6,73 & 0.07 & 0.021 \\
\hline $\mathrm{Fe}(\mathrm{mg})$ & 6.6 & 1.5 & $6 \cdot 8$ & 1.4 & 0.2 & $-0.1,0.5$ & 7.0 & 1.6 & 0.3 & $0.0,0.5$ & 0.09 & 0.031 \\
\hline $\mathrm{Zn}(\mathrm{mg})$ & 8.4 & 1.5 & 8.7 & 1.6 & 0.2 & $-0.1,0.5$ & 8.9 & 1.7 & 0.3 & $0.1,0.6$ & 0.042 & 0.016 \\
\hline $\mathrm{Cu}(\mathrm{mg})$ & 1.04 & 0.21 & 1.08 & 0.21 & 0.03 & $-0.01,0.07$ & $1 \cdot 10$ & 0.24 & 0.04 & $0.00,0.08$ & 0.08 & 0.039 \\
\hline $\mathrm{Mn}(\mathrm{mg})$ & 2.39 & 0.52 & 2.38 & 0.48 & -0.02 & $-0.12,0.07$ & 2.50 & 0.57 & 0.06 & $-0.03,0.15$ & 0.23 & 0.18 \\
\hline lodine $(\mu \mathrm{g})$ & 714 & 1718 & 685 & 1421 & -43 & $-387,301$ & 1041 & 2104 & 257 & $-57,572$ & 0.14 & 0.09 \\
\hline \multicolumn{13}{|l|}{ Food groups } \\
\hline Rice, noodles, breads, cereals (g) & 418 & 83 & 420 & 80 & -12 & $-27,3$ & 429 & 97 & -4 & $-18,10$ & 0.30 & 0.64 \\
\hline Potatoes $(\mathrm{g})$ & 58 & 29 & 60 & 31 & 2 & $-3,7$ & 55 & 26 & -4 & $-8,1$ & 0.08 & 0.10 \\
\hline Sugar $(g)$ & 7 & 5 & 8 & 5 & 1 & 0,2 & 8 & 6 & 1 & 0,2 & 0.025 & 0.008 \\
\hline Nuts and seeds $(\mathrm{g})$ & 2 & 4 & 2 & 3 & 0 & $-1,1$ & 2 & 2 & 0 & $-1,1$ & 0.94 & 0.83 \\
\hline Green vegetables (g) & 68 & 41 & 77 & 50 & 10 & 2,19 & 74 & 50 & 1 & $-7,9$ & 0.041 & 0.97 \\
\hline Other vegetables (g) & 142 & 47 & 140 & 45 & -3 & $-11,6$ & 145 & 48 & 0 & $-8,8$ & 0.79 & 0.98 \\
\hline Fruit (g) & 84 & 70 & 89 & 73 & 3 & $-11,17$ & 100 & 83 & 9 & $-4,22$ & 0.37 & 0.16 \\
\hline Mushrooms (g) & 10 & 9 & 9 & 8 & 0 & $-2,1$ & 11 & 11 & 1 & $-1,2$ & 0.57 & 0.37 \\
\hline
\end{tabular}


low-income households compared with higher-income groups were caused by differences in the types of foods consumed, and a lower consumption of fish/shellfish and green vegetables. Similar associations between household income and diet have been observed among Japanese adults. Low-income groups among Japanese adults consume less fish and vegetables and obtain more energy from carbohydrates than higher-income groups ${ }^{(26)}$, and have a higher prevalence of obesity and diabetes ${ }^{(39)}$. The association between household income and diet might affect not only adult family members, but also the children of families in Japan.

The possible pathway of this positive association might be linked to food cost. Previous studies among adults showed that positive associations exist between the cost of food and energy intake from fruits and vegetables, meat, fish and eggs, and there are inverse associations between cost of food and energy intake from fats and sugar ${ }^{(40)}$. Nutrient-dense foods, such as fruits, vegetables and fish, are more expensive than energy-dense foods ${ }^{(41)}$. A more in-depth study on purchasing behaviour revealed concerns about the cost of food in low-income families and this influenced their desire to purchase healthy foods ${ }^{(42)}$. Japanese adults in low-SES subgroups consume cheaper, lower-quality foods and nutrients ${ }^{(43)}$. These studies suggest that food cost would be an intermediator between household income and dietary intake of children. Improvement in economic factors, such as income and/or food costs, might play important roles in decreasing disparities in the diet at home among Japanese children.

We compared the nutrient intake levels with Japanese dietary guidelines to assess whether such dietary disparity is acceptable in our society. The Estimated Average Requirement (EAR) and RDA of protein for children aged 10-11 years in Japan are 40 and $50 \mathrm{~g} / \mathrm{d}$, respectively ${ }^{(44)}$. The percentage of children who consumed less protein than the EAR in low- and high-income groups was 0.6 and $0 \%$ based on averages over $4 \mathrm{~d}$, and 3.8 and $2.2 \%$ based on averages over $2 \mathrm{~d}$ without school lunch, respectively (data not shown). Most of the children of both income groups consumed more protein than the RDA based on averages over $4 \mathrm{~d}$; however, some of the children in the low-income group consumed less protein than the RDA on days without school lunch. The intake levels of Fe have more serious implications. The EAR and RDA values for $\mathrm{Fe}$ in this age group are 7.0 and $10.0 \mathrm{mg} / \mathrm{d}(14.0 \mathrm{mg} / \mathrm{d}$ for girls who are menstruating), respectively ${ }^{(44)}$. The percentage of children who consumed less Fe than the EAR in the low- and high-income groups was 65.5 and $52.6 \%$ from averages over $4 \mathrm{~d}$ and 73.0 and $60.1 \%$ from averages over $2 \mathrm{~d}$ without school lunches, respectively (data not shown). More than $65 \%$ of the children in the low-income group consumed Fe levels below the EAR and the difference between the low- and higher-income groups was more than $10 \%$. These disparities could indicate a public health problem in Japan. 
Table 3 Nutrient and food intake by household income level: average of $2 \mathrm{~d}$ with school lunch among 5 th grade children (10-11 years old) at nineteen schools in four prefectures, Japan, September-December 2013

\begin{tabular}{|c|c|c|c|c|c|c|c|c|c|c|c|c|}
\hline \multirow[b]{3}{*}{ Energy/nutrient/food group } & \multicolumn{2}{|c|}{ Low income $(n 319)$} & \multicolumn{4}{|c|}{ Middle income ( $n$ 194) } & \multicolumn{4}{|c|}{ High income $(n 323)$} & \multirow[b]{3}{*}{$P$ value $\neq$} & \multirow[b]{3}{*}{$P$ for trend } \\
\hline & \multirow[b]{2}{*}{ Mean* } & \multirow[b]{2}{*}{$S D^{*}$} & \multirow[b]{2}{*}{ Mean* } & \multirow[b]{2}{*}{$S D^{*}$} & \multicolumn{2}{|c|}{ Difference from low income } & \multirow[b]{2}{*}{ Mean* } & \multirow[b]{2}{*}{$S D^{*}$} & \multicolumn{2}{|c|}{ Difference from low income } & & \\
\hline & & & & & Meant & $95 \% \mathrm{Cl} \dagger$ & & & Mean† & $95 \% \mathrm{Cl}$ & & \\
\hline \multicolumn{13}{|l|}{ Energy and nutrients } \\
\hline Energy $(\mathrm{kJ})$ & 8335 & 1377 & 8389 & 1314 & -21 & $-268,226$ & 8556 & 1410 & 117 & $-109,339$ & 0.46 & 0.28 \\
\hline Energy (kcal) & 1992 & 329 & 2005 & 314 & -5 & $-64,54$ & 2045 & 337 & 28 & $-26,81$ & 0.46 & 0.28 \\
\hline Protein $(\mathrm{g})$ & 74.7 & $13 \cdot 6$ & $75 \cdot 2$ & $12 \cdot 3$ & -0.1 & $-2 \cdot 4,2 \cdot 3$ & $76 \cdot 6$ & $13 \cdot 0$ & 1.0 & $-1 \cdot 1,3 \cdot 2$ & 0.56 & 0.32 \\
\hline Animal protein $(\mathrm{g})$ & 44.0 & $10 \cdot 2$ & $45 \cdot 1$ & 9.4 & 0.5 & $-1 \cdot 4,2 \cdot 3$ & $45 \cdot 1$ & $10 \cdot 3$ & 0.7 & $-1 \cdot 0,2 \cdot 4$ & 0.70 & 0.42 \\
\hline Lipids (g) & 65.0 & $15 \cdot 1$ & $66 \cdot 4$ & $15 \cdot 3$ & 0.4 & $-2 \cdot 4,3 \cdot 3$ & $66 \cdot 8$ & $16 \cdot 1$ & 1.2 & $-1.4,3.8$ & 0.67 & 0.38 \\
\hline Saturated fat $(\mathrm{g})$ & 21.78 & 5.67 & $22 \cdot 25$ & 5.92 & 0.20 & $-0.86,1.26$ & $22 \cdot 12$ & $5 \cdot 87$ & 0.23 & $-0.73,1.20$ & 0.88 & 0.65 \\
\hline Cholesterol (mg) & $356 \cdot 3$ & $127 \cdot 7$ & $360 \cdot 1$ & $125 \cdot 7$ & 10.4 & $-12 \cdot 7,33 \cdot 4$ & 348.6 & $126 \cdot 5$ & -0.5 & $-21 \cdot 6,20 \cdot 5$ & 0.59 & 0.88 \\
\hline Carbohydrate $(\mathrm{g})$ & 270.0 & 46.6 & $269 \cdot 7$ & 43.6 & $-2 \cdot 2$ & $-10 \cdot 6,6 \cdot 1$ & 277.9 & 49.9 & 3.4 & $-4 \cdot 2,11 \cdot 1$ & 0.38 & 0.33 \\
\hline Dietary fibre $(\mathrm{g})$ & $13 \cdot 8$ & $3 \cdot 3$ & $13 \cdot 4$ & $2 \cdot 7$ & -0.2 & $-0.8,0.3$ & $14 \cdot 2$ & $3 \cdot 2$ & 0.2 & $-0.3,0.7$ & 0.33 & 0.39 \\
\hline Energy from protein (\%) & $15 \cdot 0$ & 1.5 & $15 \cdot 0$ & 1.4 & 0.0 & $-0.3,0.3$ & $15 \cdot 1$ & 1.5 & 0.0 & $-0.2,0.3$ & 0.93 & 0.75 \\
\hline Energy from fat (\%) & 29.1 & 3.9 & 29.5 & 4.0 & 0.2 & $-0.5,1.0$ & 29.2 & $4 \cdot 3$ & 0.2 & $-0.5,0.9$ & 0.79 & 0.62 \\
\hline Energy from carbohydrate (\%) & 55.9 & 4.3 & 55.5 & 4.3 & -0.2 & $-1.0,0.6$ & 55.7 & 4.7 & -0.2 & $-0.9,0.5$ & 0.80 & 0.59 \\
\hline Retinol activity equivalents $(\mu \mathrm{g})$ & 585 & 174 & 605 & 270 & 13 & $-39,65$ & 627 & 371 & 12 & $-36,60$ & 0.85 & 0.64 \\
\hline Vitamin D $(\mu \mathrm{g})$ & 6.5 & 4.5 & 6.5 & 4.6 & 0.2 & $-0.6,1.0$ & $7 \cdot 0$ & 5.0 & 0.3 & $-0.5,1.0$ & 0.75 & 0.45 \\
\hline $\mathrm{a}$-Tocopherol (mg) & $6 \cdot 8$ & 2.0 & $6 \cdot 7$ & 1.8 & 0.0 & $-0.3,0.4$ & 6.9 & $2 \cdot 1$ & 0.1 & $-0.2,0.4$ & 0.77 & 0.47 \\
\hline Vitamin $\mathrm{K}(\mu \mathrm{g})$ & 202 & 93 & 202 & 86 & 0.2 & $-16,17$ & 210 & 89 & 0 & $-15,15$ & 1.00 & 0.99 \\
\hline Thiamin (mg) & 1.31 & 0.32 & 1.35 & 0.34 & 0.00 & $-0.05,0.05$ & 1.31 & 0.33 & -0.02 & $-0.69,0.26$ & 0.57 & 0.35 \\
\hline Riboflavin (mg) & 1.40 & 0.38 & 1.42 & 0.31 & 0.01 & $-0.05,0.07$ & 1.43 & 0.29 & 0.00 & $-0.06,0.05$ & 0.89 & 0.85 \\
\hline Niacin equivalents (mg) & $29 \cdot 3$ & $6 \cdot 1$ & $30 \cdot 3$ & 5.5 & 0.4 & $-0.7,1.4$ & $30 \cdot 3$ & $6 \cdot 1$ & 0.4 & $-0.6,1.4$ & 0.72 & 0.48 \\
\hline Vitamin $\mathrm{B}_{6}(\mathrm{mg})$ & 1.32 & 0.60 & 1.33 & 0.33 & -0.01 & $-0.10,0.07$ & 1.34 & 0.32 & -0.02 & $-0.10,0.06$ & 0.88 & 0.63 \\
\hline Vitamin $B_{12}(\mu \mathrm{g})$ & $5 \cdot 7$ & 3.4 & $5 \cdot 6$ & 3.0 & -0.1 & $-0.8,0.5$ & $6 \cdot 2$ & $4 \cdot 3$ & 0.3 & $-0.2,0.9$ & 0.28 & 0.21 \\
\hline Folate $(\mu \mathrm{g})$ & 308 & 80 & 293 & 69 & -8 & $-21,6$ & 316 & 87 & 1 & $-11,13$ & 0.38 & 0.76 \\
\hline Pantothenic acid (mg) & $7 \cdot 11$ & 1.37 & 7.24 & 1.30 & 0.09 & $-0.15,0.33$ & 7.31 & 1.34 & 0.11 & $-0.11,0.32$ & 0.62 & 0.36 \\
\hline Biotin ( $u \mathrm{~g})$ & $34 \cdot 2$ & $10 \cdot 0$ & 33.3 & 8.9 & 0.1 & $-1.6,1.8$ & 34.6 & 11.2 & 0.0 & $-1.6,1.6$ & 0.99 & 0.99 \\
\hline Vitamin C $(\mathrm{mg})$ & 111 & 50 & 107 & 34 & -7 & $-15,1$ & 113 & 43 & 5 & $-13,2$ & 0.16 & 0.20 \\
\hline $\mathrm{Na}(\mathrm{mg})$ & 3791 & 737 & 3866 & 747 & -13 & $-145,119$ & 3910 & 728 & 28 & $-92,149$ & 0.80 & 0.61 \\
\hline $\mathrm{K}(\mathrm{mg})$ & 2652 & 536 & 2672 & 463 & -1 & $-93,91$ & 2750 & 508 & 25 & $-59,109$ & 0.80 & 0.54 \\
\hline $\mathrm{Ca}(\mathrm{mg})$ & 698 & 185 & 693 & 169 & -7 & $-39,25$ & 720 & 173 & 6 & $-23,35$ & 0.71 & 0.63 \\
\hline $\mathrm{Mg}(\mathrm{mg})$ & 246 & 50 & 245 & 42 & -3 & $-12,6$ & 258 & 51 & 5 & $-3,13$ & 0.17 & 0.19 \\
\hline$P(\mathrm{mg})$ & 1183 & 223 & 1189 & 198 & -2 & $-40,36$ & 1213 & 206 & 12 & $-22,47$ & 0.68 & 0.45 \\
\hline $\mathrm{Fe}(\mathrm{mg})$ & 7.0 & 1.7 & 7.0 & 1.4 & 0.0 & $-0.3,0.3$ & 7.4 & 1.9 & 0.0 & $-0.1,0.5$ & 0.24 & 0.15 \\
\hline $\mathrm{Zn}(\mathrm{mg})$ & $9 \cdot 1$ & 1.6 & $9 \cdot 2$ & 1.7 & 0.0 & $-0.3,0.4$ & $9 \cdot 4$ & 1.9 & 0.2 & $-0.1,0.5$ & 0.44 & 0.21 \\
\hline $\mathrm{Cu}(\mathrm{mg})$ & $1 \cdot 12$ & 0.22 & $1 \cdot 13$ & 0.21 & 0.00 & $-0.04,0.04$ & $1 \cdot 16$ & 0.24 & 0.02 & $-0.02,0.05$ & 0.56 & 0.32 \\
\hline $\mathrm{Mn}(\mathrm{mg})$ & 2.52 & 0.57 & 2.50 & 0.52 & -0.05 & $-0.15,0.06$ & 2.64 & 0.63 & 0.05 & $0.05,0.15$ & 0.22 & 0.28 \\
\hline & 806 & 1988 & 639 & 1425 & -221 & $-635,192$ & 1015 & 2643 & 82 & $-295,460$ & 0.33 & 0.57 \\
\hline \multicolumn{13}{|l|}{$\begin{array}{l}\text { Iodine }(\mu \mathrm{g}) \\
\text { Food groups }\end{array}$} \\
\hline Rice, noodles, breads, cereals ( $\mathrm{g}$ ) & 412 & 85 & 424 & 84 & -5 & $-21,10$ & 425 & 101 & -1 & $-15,13$ & 0.79 & 0.94 \\
\hline Potatoes $(\mathrm{g})$ & 73 & 38 & 72 & 41 & 1 & $-6,7$ & 70 & 37 & -4 & $-9,2$ & 0.30 & $0 \cdot 18$ \\
\hline Sugar $(g)$ & 9 & 6 & 9 & 6 & 0 & $-1,2$ & 9 & 9 & 1 & $-1,2$ & 0.67 & 0.42 \\
\hline Nuts and seeds $(\mathrm{g})$ & 2 & 5 & 2 & 4 & 0 & $-1,1$ & 2 & 3 & 0 & $-1,1$ & 0.90 & $0 \cdot 70$ \\
\hline Green vegetables $(\mathrm{g})$ & 80 & 47 & 85 & 48 & 6 & $-3,15$ & 85 & 53 & 3 & $-5,11$ & 0.39 & 0.57 \\
\hline Other vegetables $(\mathrm{g})$ & 175 & 58 & 173 & 54 & -5 & $-14,5$ & 181 & 59 & -1 & $-10,8$ & 0.60 & 0.90 \\
\hline Fruit (g) & 89 & 75 & 94 & 78 & 0 & $-15,16$ & 106 & 97 & 7 & $-7,21$ & 0.53 & 0.29 \\
\hline Mushrooms (g) & 11 & 11 & 10 & 10 & 0 & $-2,1$ & 12 & 12 & 1 & $-1,2$ & 0.36 & 0.29 \\
\hline
\end{tabular}


Difference in associations of income with dietary intake between days with and without school lunch

Our results showed that the association between household income and dietary intake was reduced during days with school lunch. This might be the first evidence to show a difference between days with school lunch and days without in association with household income and dietary intake in primary-school children. One reason might be that food and nutrient composition in school lunches can make up for the differences in food and nutrient intake at home. Standard amounts of nutrients and food groups must be provided for each child per meal at school lunch in Japan and school lunches provide more than one-third of the dietary requirements per day. Moreover, food eaten on non-school days and non-school meals occurred on the weekend. Weekend meals might be more sensitive to household economic status. Low-income groups might consume less nutritious foods at the weekend compared with weekdays, and the difference in diet between weekend days and weekdays might be larger than that in high-income groups. Some reports from the USA suggest that the school lunch programme for children in lowincome households is an effective way to improve dietary quality and prevent obesity ${ }^{(31-34)}$. However, a systematic review of the effects of school-based health interventions, including school lunches, on SES disparities in health concluded that the effects are unclear ${ }^{(45)}$. School lunch programmes would be effective in terms of food security for children in low-SES households, but their effects on dietary behaviour and improving nutrition at home have not been clarified. Further research into whether school lunches reduce dietary disparities might be useful for deciding on additional school-based health intervention policies for children.

\section{Study limitations}

Our study has several limitations. First, sampling bias should be considered. The study participants were not selected randomly from the Japanese population. We selected several public primary schools that we contacted through the local governments and invited all 5 th grade students to participate. If all these students participated in the study, low-income participants would be included at almost the same rate as in the Japanese population. We also need to improve the quality of the dietary records. We need to explain how to write a dietary record and how to take a photograph for children. If the participants are scattered, it is difficult to explain and exercise the same quality. Second, the response rate to our study was high $(85.1 \%)$, but many participants opted not to answer questions about income (307 out of 1231 participants) and the final response rate was only $57 \cdot 8 \%$. To compare the percentage distribution of each household with primary-school children based on annual incomes of representative data in fiscal year $2012^{(23)}$ and the present study: less than 1 million yen, 1.4 and $0.7 \%$; 


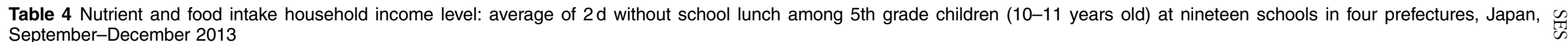

\begin{tabular}{|c|c|c|c|c|c|c|c|c|c|c|c|c|}
\hline \multirow[b]{3}{*}{ Energy/nutrient/food group } & \multicolumn{2}{|c|}{ Low income $(n 319)$} & \multicolumn{4}{|c|}{ Middle income ( $n$ 194) } & \multicolumn{4}{|c|}{ High income ( $n$ 323) } & \multirow[b]{3}{*}{$P$ value $\ddagger$} & \multirow[b]{3}{*}{$P$ for trend§ } \\
\hline & \multirow[b]{2}{*}{ Mean* $^{*}$} & \multirow[b]{2}{*}{$\mathrm{SD}^{*}$} & \multirow[b]{2}{*}{ Mean* } & \multirow[b]{2}{*}{$\mathrm{SD}^{*}$} & \multicolumn{2}{|c|}{ Difference from low income } & \multirow[b]{2}{*}{ Mean* } & \multirow[b]{2}{*}{$\mathrm{SD}^{*}$} & \multicolumn{2}{|c|}{ Difference from low income } & & \\
\hline & & & & & Meant & $95 \% \mathrm{Cl}$ & & & Meant & $95 \% \mathrm{Cl}$ & & \\
\hline \multicolumn{13}{|l|}{ Energy and nutrients } \\
\hline Energy $(\mathrm{kJ})$ & 7590 & 1657 & 7803 & 1619 & 105 & $-201,414$ & 7971 & 1715 & 234 & $-46,515$ & 0.26 & $0 \cdot 10$ \\
\hline Energy (kcal) & 1814 & 396 & 1865 & 387 & 25 & $-48,99$ & 1905 & 410 & 56 & $-11,123$ & 0.26 & 0.10 \\
\hline Protein $(\mathrm{g})$ & 64.4 & 14.8 & $68 \cdot 0$ & $16 \cdot 6$ & 3.0 & $0 \cdot 0,6 \cdot 0$ & 70.5 & $17 \cdot 2$ & 5.5 & $2 \cdot 7,8 \cdot 2$ & $<0.001$ & $<0.001$ \\
\hline Animal protein (g) & $35 \cdot 2$ & $11 \cdot 7$ & 38.5 & $13 \cdot 3$ & $2 \cdot 8$ & $0.4,5 \cdot 3$ & $40 \cdot 2$ & 14.6 & $5 \cdot 1$ & $2 \cdot 8,7 \cdot 3$ & $<0.001$ & $<0.001$ \\
\hline Lipids $(\mathrm{g})$ & 59.9 & 18.8 & 63.9 & 18.8 & $2 \cdot 3$ & $-1 \cdot 3,5 \cdot 9$ & 64.6 & $19 \cdot 8$ & 3.2 & $-0.1,6 \cdot 4$ & 0.15 & 0.06 \\
\hline Saturated fat $(\mathrm{g})$ & $18 \cdot 26$ & 6.76 & $19 \cdot 56$ & 6.96 & 0.90 & $-0 \cdot 40,2 \cdot 10$ & 19.52 & 7.02 & 0.50 & $-0.68,1.67$ & 0.42 & 0.47 \\
\hline Cholesterol (mg) & 334.3 & $139 \cdot 2$ & 365.6 & 161.5 & $21 \cdot 1$ & $-7 \cdot 4,50 \cdot 0$ & $372 \cdot 8$ & $155 \cdot 7$ & 33.0 & $7 \cdot 0,59 \cdot 0$ & 0.043 & 0.014 \\
\hline Carbohydrate (g) & $247 \cdot 4$ & 55.5 & $247 \cdot 1$ & 51.4 & $-2 \cdot 0$ & $-12 \cdot 2,8 \cdot 1$ & 253.0 & $57 \cdot 4$ & $1 \cdot 1$ & $-8 \cdot 2,10 \cdot 3$ & 0.83 & 0.78 \\
\hline Dietary fibre $(\mathrm{g})$ & $11 \cdot 0$ & 3.5 & 11.5 & 3.5 & 0.5 & $-1 \cdot 0,1 \cdot 1$ & 11.5 & $3 \cdot 3$ & 0.2 & $-0.4,0.8$ & 0.31 & 0.59 \\
\hline Energy from protein (\%) & 14.4 & 1.9 & $14 \cdot 6$ & 1.9 & 0.3 & $-0.7,0.7$ & 14.9 & $2 \cdot 1$ & 0.6 & $0.3,1.0$ & 0.001 & $<0.001$ \\
\hline Energy from fat (\%) & 29.1 & 4.9 & $30 \cdot 3$ & $5 \cdot 0$ & 0.8 & $-0 \cdot 2,1 \cdot 7$ & $30 \cdot 1$ & $5 \cdot 3$ & 0.8 & $-0 \cdot 1,1 \cdot 7$ & 0.14 & 0.09 \\
\hline Energy from carbohydrate (\%) & 56.5 & $5 \cdot 3$ & $55 \cdot 1$ & $5 \cdot 7$ & $-1 \cdot 1$ & $-2 \cdot 2,0.0$ & $55 \cdot 0$ & $6 \cdot 0$ & $-1 \cdot 4$ & $-2.4,-0.5$ & 0.012 & 0.005 \\
\hline Retinol activity equivalents $(\mu \mathrm{g})$ & 395 & 229 & 427 & 232 & 25 & $-15,70$ & 425 & 227 & 2 & $-37,40$ & 0.37 & 0.96 \\
\hline Vitamin D $(\mu \mathrm{g})$ & 4.9 & 4.3 & 5.3 & 4.8 & 0.2 & $-0.7,1.1$ & 5.7 & $5 \cdot 2$ & 0.8 & $0.0,1.6$ & 0.15 & 0.06 \\
\hline a-Tocopherol (mg) & $6 \cdot 2$ & $2 \cdot 2$ & $6 \cdot 6$ & $2 \cdot 2$ & 0.3 & $-0.1,0.7$ & $6 \cdot 8$ & $2 \cdot 2$ & 0.5 & $0.1,9.0$ & 0.034 & 0.011 \\
\hline Vitamin $\mathrm{K}(\mu \mathrm{g})$ & 162 & 100 & 173 & 98 & 14 & $-4,32$ & 170 & 90 & 5 & $-11,22$ & 0.30 & 0.62 \\
\hline Thiamin (mg) & 0.96 & 0.30 & 0.96 & 0.31 & 0.00 & $-0.05,0.06$ & 1.00 & 0.30 & 0.03 & $-0.03,0.08$ & 0.61 & 0.33 \\
\hline Riboflavin (mg) & 1.05 & 0.37 & $1 \cdot 12$ & 0.41 & 0.07 & $-0.01,0.14$ & 1.13 & 0.37 & 0.06 & $-0.01,0.12$ & 0.13 & 0.12 \\
\hline Niacin equivalents (mg) & $26 \cdot 2$ & $7 \cdot 2$ & $27 \cdot 5$ & $7 \cdot 4$ & 1.2 & $-0 \cdot 2,2 \cdot 7$ & 28.7 & 8.4 & $2 \cdot 5$ & $1 \cdot 2,3 \cdot 8$ & 0.001 & $<0.001$ \\
\hline Vitamin $\mathrm{B}_{6}(\mathrm{mg})$ & 1.07 & 0.47 & 1.14 & 0.40 & 0.07 & $-0.01,0.15$ & 1.15 & 0.35 & 0.07 & $0.00,0.14$ & 0.083 & 0.06 \\
\hline Vitamin $B_{12}(\mu \mathrm{g})$ & 4.7 & $3 \cdot 2$ & $5 \cdot 7$ & $4 \cdot 4$ & 1.0 & $0.2,1.7$ & 6.0 & 4.6 & 1.4 & $0.7,2.1$ & $<0.001$ & $<0.001$ \\
\hline Folate $(\mu \mathrm{g})$ & 230 & 81 & 243 & 88 & 16 & 0,31 & 247 & 83 & 12 & $-2,26$ & 0.10 & 0.14 \\
\hline Pantothenic acid (mg) & 5.47 & 1.53 & $5 \cdot 83$ & 1.55 & 0.31 & $0.02,0.60$ & 5.93 & 1.58 & 0.34 & $0.08,0.60$ & 0.024 & 0.016 \\
\hline Biotin $(\mu \mathrm{g})$ & 24.9 & $10 \cdot 0$ & $27 \cdot 1$ & $11 \cdot 1$ & $1 \cdot 7$ & $-0.2,3.7$ & $27 \cdot 0$ & 10.5 & 1.6 & $-0.2,3.4$ & 0.14 & 0.11 \\
\hline Vitamin C (mg) & 84 & 55 & 103 & 172 & 18 & 0,36 & 90 & 53 & -1 & $-18,16$ & 0.07 & 0.74 \\
\hline $\mathrm{Na}(\mathrm{mg})$ & 3509 & 860 & 3556 & 894 & 37 & $-130,204$ & 3663 & 943 & 105 & $-47,257$ & 0.38 & 0.17 \\
\hline $\mathrm{K}(\mathrm{mg})$ & 1970 & 607 & 2091 & 591 & 133 & 22,244 & 2127 & 602 & 113 & 11,214 & 0.031 & 0.044 \\
\hline $\mathrm{Ca}(\mathrm{mg})$ & 423 & 182 & 453 & 206 & 29 & $-7,66$ & 455 & 197 & 16 & $-17,50$ & 0.29 & 0.41 \\
\hline $\mathrm{Mg}(\mathrm{mg})$ & 194 & 54 & 203 & 53 & 10 & 0,21 & 209 & 55 & 13 & 3, 22 & 0.019 & 0.009 \\
\hline$P(\mathrm{mg})$ & 931 & 240 & 986 & 258 & 50 & 3,97 & 1014 & 266 & 67 & 24,110 & 0.008 & 0.003 \\
\hline $\mathrm{Fe}(\mathrm{mg})$ & $6 \cdot 2$ & 1.9 & 6.6 & 1.9 & 0.4 & $0.1,0.7$ & 6.6 & 1.9 & 0.4 & $0.1,0.7$ & 0.029 & 0.029 \\
\hline $\mathrm{Zn}(\mathrm{mg})$ & $7 \cdot 7$ & $2 \cdot 1$ & $8 \cdot 2$ & $2 \cdot 1$ & 0.4 & $0.0,0.8$ & 8.3 & $2 \cdot 2$ & 0.5 & $0.1,0.8$ & 0.018 & 0.012 \\
\hline $\mathrm{Cu}(\mathrm{mg})$ & 0.97 & 0.25 & 1.04 & 0.29 & 0.06 & $0.01,0.12$ & 1.04 & 0.33 & 0.06 & $0.01,0.11$ & 0.028 & 0.023 \\
\hline $\mathrm{Mn}(\mathrm{mg})$ & $2 \cdot 27$ & 0.63 & $2 \cdot 25$ & 0.64 & 0.01 & $-0.12,0.13$ & 2.35 & 0.71 & 0.06 & $-0.05,0.17$ & 0.49 & 0.26 \\
\hline lodine $(\mu \mathrm{g})$ & 622 & 2261 & 732 & 2206 & 135 & $-350,621$ & 1068 & 3037 & 433 & $-11,876$ & 0.15 & 0.05 \\
\hline \multicolumn{13}{|l|}{ Food groups } \\
\hline Rice, noodles, breads, cereals ( $\mathrm{g}$ ) & 423 & 110 & 417 & 107 & -18 & $-39,2$ & 432 & 119 & -8 & $-28,11$ & 0.21 & 0.52 \\
\hline Potatoes $(\mathrm{g})$ & 43 & 40 & 48 & 45 & 4 & $-4,11$ & 41 & 34 & -3 & $-10,3$ & 0.18 & 0.26 \\
\hline Sugar $(g)$ & 5 & 6 & 7 & 7 & 1 & 0,3 & 7 & 8 & 2 & 1,3 & 0.004 & 0.001 \\
\hline Nuts and seeds $(\mathrm{g})$ & 1 & 5 & 1 & 4 & 0 & $-1,1$ & 1 & 3 & 0 & 0,1 & 0.71 & 0.42 \\
\hline Green vegetables ( $\mathrm{g}$ ) & 56 & 50 & 69 & 65 & 14 & 4,25 & 62 & 58 & -1 & $-11,9$ & 0.008 & 0.61 \\
\hline Other vegetables (g) & 110 & 58 & 107 & 58 & 0 & $-11,10$ & 110 & 57 & 1 & $-9,10$ & 0.98 & 0.89 \\
\hline Fruit (g) & 80 & 87 & 85 & 96 & 7 & $-11,24$ & 94 & 98 & 11 & $-5,27$ & 0.40 & 0.18 \\
\hline Mushrooms (g) & 8 & 11 & 8 & 10 & 0 & $-2,3$ & 9 & 15 & 0 & $-2,3$ & 0.90 & 0.65 \\
\hline
\end{tabular}


1 to less than 2 million yen, $6 \cdot 1$ and $4 \cdot 3 \%$; 2 to less than 3 million yen, 6.8 and $7.3 \%$; 3 to less than 4 million yen, 8.9 and $12.3 \%$; 4 to less than 6 million yen, 25.7 and $32.9 \%$; 6 to less than 8 million yen, 21.3 and $25.8 \%$; 8 or more million yen, 29.8 and $16.7 \%$, respectively. The percentage distribution of households by household income in the present study was similar to national representative data. However, the difference between the national sample and the present study was small for low income levels, and the percentage of households that have 8 or more million yen was lower in the present study. The disparity of the diet in our study would be underestimated compared with that on a national level.

\section{Policy implications}

The present study's results have important implications for nutritional policy. They revealed independent effects of income on diet after adjusting for related variables including parental education. This suggested that economic support might effectively increase the amount of protein and other micronutrients consumed in low-income households.

Our study revealed that income-related dietary disparities in children were not significant on days with school lunches, but significant on days without. This suggests that the school lunch programme might play an important role in reducing dietary disparity in children of low SES. However, school lunches are available for only $190 \mathrm{~d} /$ year at Japanese public primary schools; therefore, children do not have access to school lunches for the remaining $185 \mathrm{~d}$. A meal programme for children at school or in the community might be recommended during the summer and other vacations.

\section{Conclusion}

Our study confirmed an association between household income and amounts of foods and nutrients consumed by Japanese schoolchildren using $4 \mathrm{~d}$ dietary records. Lower income level was associated with a lower intake of fish/ shellifish, green vegetables and sugar at the food group level, a lower intake of protein and several micronutrients, and a higher energy intake from carbohydrates at the nutrient level among the children.

Moreover, we found variations in the association between household income and the food/nutrients children consumed, which depended on whether school lunches were consumed or not. The disparities in foods and nutrients consumed among the income groups were not significant on days with school lunches, while they were significant on days without school lunches. The evidence suggests the importance of school lunches for reducing disparities in the diets of children from households with various incomes. 
Acknowledgements

Acknowledgements: The authors thank the volunteer subjects and their families who participated in this study. They are also greatly indebted to the primary schools and the Boards of Education in the cities. They thank Professor Naohito Tanabe for his contribution to the statistical analysis. Financial support: This research was supported by a Health and Labour Sciences Research Grant (Comprehensive Research on Life Style-related Diseases Including Cardiovascular Diseases and Diabetes Mellitus (N.M.; grant number H24-H26 Jyunkankitou-Seisyu-Ippan-006)) by the Ministry of Health Labour and Welfare, Japan; and a Grantin-Aid for Scientific Research (KAKENHI) (N.M.; grant number 15K00728) by the Japan Society for the Promotion of Science. The funders had no role in the design, analysis or writing of this article. Conflict of interest: None. Authorship: N.M. formulated the research question, designed the study, conducted the study, analysed the data and wrote the article. H.I., T.Y. and S.H. designed the study, conducted the study and analysed the data. A.N., Y.A., M.N., Y.Y. and S.S. conducted the study and analysed the data. A.A. formulated the research question and designed the study. Ethics of human subject participation: This study was conducted according to the guidelines laid down in the Declaration of Helsinki and all procedures involving human subjects/patients were approved by the ethics committee of the University of Niigata Prefecture, Japan (number 1309). Written informed consent was obtained from all subjects/patients.

\section{References}

1. Marmot M \& Wilkinson RG (2005) Social Determinants of Health, 2nd ed. New York: Oxford University Press.

2. James WP, Nelson M, Ralph A et al. (1997) Socioeconomic determinants of health. The contribution of nutrition to inequalities in health. BMJ 314, 1545-1549.

3. Smith GD \& Brunner E (1997) Socio-economic differentials in health: the role of nutrition. Proc Nutr Soc 56, 75-90.

4. Darmon N \& Drewnowski A (2008) Does social class predict diet quality? Am J Clin Nutr 87, 1107-1117.

5. Irala-Estevez JD, Groth M, Johansson L et al. (2000) A systematic review of socio-economic differences in food habits in Europe: consumption of fruit and vegetables. Eur J Clin Nutr 54, 706-714.

6. Lopez-Azpiazu I, Sanchez-Villegas A, Johansson L et al. (2003) Disparities in food habits in Europe: systematic review of educational and occupational differences in the intake of fat. J Hum Nutr Diet 16, 349-364.

7. Sanchez-Villegas A, Martines JA, Prattala R et al. (2003) A systematic review of socioeconomic differences in food habits in Europe: consumption of cheese and milk. Eur J Clin Nutr 57, 917-929.

8. MeJean C, Hassen WS, Lecossais C et al. (2016) Socioeconomic indicators are independently associated with intake of animal foods in French adults. Public Health Nutr 19, 3146-3157.

9. Hassen WS, Castetbon K, Cardon P et al. (2016) Socioeconomic indicators are independently associated with nutrient intake in French adults: a DEDIPAC study. Nutrients $\mathbf{8}, 158$.
10. El-Sayed AM, Scarborough P \& Galea S (2012) Socioeconomic inequalities in childhood obesity in the United Kingdom: a systematic review of the literature. Obes Facts 5, 671-692.

11. Barrisuo L, Miqueleiz E, Albaladejo R et al. (2015) Socioeconomic position and childhood-adolescent weight status in rich countries: a systematic review, 1990-2013. BMC Pediatr 15, 129.

12. Senese LC, Almeida ND, Fath AK et al. (2009) Associations between childhood socioeconomic position and adulthood obesity. Epidemiol Rev 31, 21-51.

13. Eloranta AM, Lindi V, Schwab U et al. (2011) Dietary factors and their associations with socioeconomic background in Finnish girls and boys $6-8$ years of age: the PANIC study. Eur J Clin Nutr 65, 1211-1218.

14. Sausenthaler S, Standl M, Buyken A et al. (2011) Regional and socio-economic differences in food, nutrient and supplement intake in school-age children in Germany: result from the GINIplus and the LISAplus studies. Public Health Nutr 14, 1724-1735.

15. Bau AM, Krull S, Ernert A et al. (2011) Eating behaviour and its association with social living conditions and weight status among adolescent girls: results of the cross-sectional Berlin School Children's Cohort study. Public Health Nutr 14, 1759-1767.

16. Finger JD, Varnaccia G, Tylleskar T et al. (2015) Dietary behavior and parental socioeconomic position among adolescents: the German Health Interview and Examination Survey for Children and Adolescents 2003-2006 (KiGGS). BMC Public Health 15, 498.

17. Northstone K, Smith A DAC, Cribb VL et al. (2013) Dietary patterns in UK adolescents obtained from a dual-source FFQ and their associations with socio-economic position, nutrient intake and modes of eating. Public Health Nutr 17, 1476-1485.

18. Fernandez-Alvia JM, Bornhorst C, Bammann K et al. (2015) Prospective associations between socio-economic status and dietary patterns in European children: the Identification and Prevention of Dietary- and Lifestyle-induced Health Effects in Children and Infants (IDEFICS) study. Br J Nutr 113, $517-525$.

19. Mark S, Lambert M, O'Loughlin J et al. (2012) Household income, food insecurity and nutrition in Canadian youth. Can J Public Health 103, 94-99.

20. Kwon Y, Oh S, Park S et al. (2010) Association between household income and overweight Korean and American children: trends and differences. Nutr Res 30, 470-476.

21. Navakovic R, Cavelaars A, Geelen A et al. (2013) Socioeconomic determinants of micronutrient intake and status in Europe: a systematic review. Public Health Nutr 17, 1031-1045.

22. Marmot MG \& Smith GD (1989) Why are the Japanese living longer? BMJ 299, 1547-1551.

23. Ministry of Health, Labour and Welfare of Japan (2014) Comprehensive Survey of Living Conditions 2013 (in Japanese). http://www.mhlw.go.jp/toukei/saikin/hw/ k-tyosa/k-tyosa13/index.html (accessed August 2016).

24. Kagamimori S, Gaina A \& Nasermoaddeli A (2009) Socioeconomic status and health in the Japanese population. Soc Sci Med 68, 2152-2160.

25. Fukuda Y \& Hiyoshi A (2012) High quality nutrient intake is associated with higher household expenditures by Japanese adults. BioSci Trends 6, 176-182.

26. Nishi N, Horikawa C \& Murayama N (2017) Characteristics of food group intake by household income in the National Health and Nutrition Survey, Japan. Asia Pac J Clin Nutr 26, 156-159.

27. Okubo H, Miyake Y, Sasaki S et al. (2014) Dietary patterns in infancy and their associations with maternal socioeconomic and lifestyle factors among 758 Japanese mother-child pairs: the Osaka maternal and Child Health Study. Matern Child Nutr 10, 213-225. 
28. Tanaka N \& Miyoshi M (2012) School lunch program for health promotion among children in Japan. Asia Pac J Clin Nutr 21, 155-158.

29. Ishida H (2015) Role of school meal service in nutrition. J Nutr Sci Vitaminol (Tokyo) 61, Suppl., S20-S22.

30. Ministry of Education, Culture, Sports, Science and Technology Japan (2016) School lunch survey in Japan 2014 (in Japanese). http://www.mext.go.jp/b_menu/toukei/ chousa05/kyuushoku/1267027.htm (accessed August 2016).

31. Huang J \& Bamidge E (2016) Low-income children's participation in the national school lunch program and household food insufficiency. Soc Sci Med 150, 8-14.

32. Cullen KW \& Chen T (2017) The contribution of the USDA school breakfast and lunch program meals to student daily dietary intake. Prev Med 5, 82-85.

33. Kimbro RT \& Rigby E (2010) Federal food policy and childhood obesity: a solution or part of the problem? Health Aff (Millwood) 29, 411-418.

34. Nguen BT, Ford CN, Yaroch AL et al. (2017) Food security and weight status in children: interactions with food assistance programs. Am J Prev Med 52, Suppl. 2, S138-S144.

35. Organisation for Economic Co-operation and Development (2008) Growing Unequal? Income Distribution and Poverty in OECD Country. Paris: OECD.

36. Kondo N, Kawachi I, Hirai I et al. (2009) relative deprivation and incident functional disability among older Japanese women and men: prospective cohort study. J Epidemiol Community Health 63, 461-467.

37. Ministry of Education, Culture, Sports, Science and Technology Japan (2015) Manual for Health Checkup of School Children, Revision in 2015, (in Japanese). Tokyo: Gakko hokenkai; available at http://www.gakkohoken.jp/book/ ebook/ebook_H270030/index_h5.html
38. Kachi Y, Otsuka T \& Kawada T (2015) Socioeconomic status and overweight: a population-based cross-sectional study of Japanese children and adolescents. J Epidemiol 25, 463-469.

39. Horikawa C, Murayama N, Ota A et al. (2017) Prevalence of non-communicable diseases and number of comorbidities according to differences in household income levels in Japan: analysis from national health and nutrition survey. Food Nutr Sci 8, 19-30.

40. Drewnowski A \& Specter SE (2004) Poverty and obesity: the role of energy density and energy costs. Am J Clin Nutr 79, 6-16.

41. Darmon N \& Drewnowski A (2015) Contribution of food prices and diet cost to socioeconomic disparities in diet quality and health: a systematic review. Nutr Rev 73, 643-660.

42. Turrell G \& Kavanagh AM (2006) Socio-economic pathways to diet: modelling the association between socio-economic position and food purchasing behaviour. Public Health Nutr 9, 375-383.

43. Okubo H, Murakami K \& Sasaki S (2016) Monetary value of self-reported diets and associations with sociodemographic characteristics and dietary intake among Japanese adults: analysis of nationally representative surveys. Public Health Nutr 19, 3306-3318.

44. Ministry of Health, Labour and Welfare of Japan (2014) Overview of dietary reference intakes for Japanese (2015). http://www.mhlw.go.jp/file/06-Seisakujouhou-10900000Kenkoukyoku/Overview.pdf (accessed March 2017).

45. Moore GF, Littlecott HJ, Turley R et al. (2015) Socioeconomic gradients in the effects of universal school-based health behavior interventions: a systematic review of intervention studies. BMC Public Health 15, 907. 